\title{
Increased Respiratory Secretion
}

National Cancer Institute

\section{Source}

National Cancer Institute. Increased Respiratory Secretion. NCI Thesaurus. Code C121630.

An increase in respiratory secretions. 